\title{
ПРО ПРАВА МЕДИЧНИХ ПРАЦІВНИКІВ ПІД ЧАС НАДАННЯ МЕДИЧНОЇ ДОПОМОГИ В КОНТЕКСТІ РЕФОРМУВАННЯ СИСТЕМИ ОХОРОНИ ЗДОРОВ'Я
}

\author{
${ }^{1}$ ВДНЗ «Буковинський державний медичний університет», м. Чернівці, Україна \\ ${ }^{2}$ ДВНЗ «Тернопільський державний медичний університет імені І. Я. Горбачевського МОЗ України», \\ м. Тернопіль, Україна
}

\begin{abstract}
Мета: з'ясувати існуючі права медичних працівників, передбачені чинним законодавством, 3 огляду на ресормування системи охорони здоров'я.

Матеріали і методи. Методологічною основою дослідження виступає сукупність загальних та спеціальних наукових методів пізнання. Чинні нормативно-правові акти, що проаналізовано за допомогою комплексу методів: порівняльно-правового, структурно-логічного, системно-аналітичного, формально-логічного та методу теоретичного аналізу з дотриманням принципів біотичних норм і правил; фрормулювання і систематизація висновків.

Результати. Аналіз чинних нормативно-правових актів дає підстави стверджувати, що права медичних працівників слід розмежувати на дві групи: загальні та спеціальні. До загальних прав медичних працівників належать ті, які гарантують певні умови їх професійної діяльності, охорону здоров'я, соціальний захист, зокрема право на: належні умови професійної діяльності; обов'язкове страхування; створення медичних наукових товариств чи професійних спілок; судовий захист; соціальну допомогу; скорочений робочий день і додаткову відпустку; пільгові умови пенсійного забезпечення та пільгове надання житла; першочергову медичну допомогу тощо. До спеціальних прав належать такі, які передбачені виключно для медичного працівника як спеціального суб'єкта. Серед таких прав необхідно виокремити: право про надання інформації про пацієнта без його згоди чи згоди його законного представника; право на відмову від подальшого ведення пацієнта; право здійснювати медичне втручання без згоди пацієнта або його законних представників.

Чинне національне законодавство у галузі охорони здоров'я потребує вдосконалення. Одним із кроків на цьому шляху стала би імплементація передбаченого міжнародними нормативними актами права лікаря на заперечення під час виконання своїх професійних обов'язків.

Висновки. Права лікаря при наданні медичної допомоги слід розділити на загальні та спеціальні. Передбачені чинним національним законодавством професійні права медичних працівників не завжди забезпечуються державними гарантіями і мають почасти декларативний характер. Це зумовлено відсутністю розроблених підзаконних актів, які повинні забезпечити механізм їх реалізації з урахуванням вимог сьогодення. Застосування зарубіжного досвіду, імплементація міжнародних стандартів у національне законодавство, зокрема щодо реалізації лікарем права на заперечення з міркувань совісті, забезпечить більш професійну захищеність лікаря та підвищить якість надання медичної допомоги.
\end{abstract}

КЛЮчОВІ СЛОВА: система охорони здоров’я; права; медичний працівник; медична допомога.

Динамічний розвиток суспільства зумовлює вдосконалення існуючих та виникнення нових профресій. Діяльність працівника у будь-якій професійній галузі повинна охоплювати належні знання та високу пізнавальну активність, самостійність, майстерність і кваліфрікованість, інтерес до власних трудових і функціональних обов'язків. Не є винятком і галузь охорони здоров'я, де профресійна діяльність медичного працівника має свої специорічні особливості, які кардинально відрізняють професію лікаря від інших. Серед цих особливостей варто відзначити насамперед велику суспільну значимість та унікальність самого об'єкта профресійної медичної діяльності, яким є життя і здоров'я громадян, що, відповідно до ст. 3 Конституції України, визнається державою як найвища

(c) І. Г. Савка, Н. М. Калинюк, 2019 соціальна цінність. Доречно зазначав у своїх працях В. Франчук, що одним із основних показників оцінки загального розвитку країни є рівень технічної оснащеності профресії медика, матеріальної забезпеченості та професійної кваліфікованості лікарів тощо [8].

3 набуттям чинності цілої низки прийнятих протягом останніх кількох років спеціальних законодавчих актів, 31 січня 2018 р. в Україні дано старт медичній рефрормі, головними принципами якої, відповідно до «Національної стратегії реформування системи охорони здоров'я в Україні на період 2015-2020 років», стали орієнтованість на людей, орієнтованість на результат і орієнтованість на втілення. Згідно зі Стратегією, система охорони здоров'я «має дослухатися до потреб людей (пацієнтів, працівників); якість та безпека послуг, їх здатність адаптуватися до вимог і 
викликів, котрі постійно змінюються, є головними засадами системи охорони здоров'я, що будуть сорормовані у результаті рефрорм».

Крім орієнтованості на пацієнта, відповідно до реформи медичної галузі, підвищуються вимоги до рівня підготовки медичних кадрів, які, крім належної профресійної кваліфікації, повинні також мати базисні знання про передбачені законом правові засади своєї практичної діяльності [7]. Основні теоретичні й практичні проблеми, пов'язані 3 систематизацією законодавства у галузі охорони здоров'я, аналізу правового статусу лікаря, не отримали достатню системну та комплексну розробку. 3 цих причин, у контексті медичної реформи, систематизація чинного законодавства, що регулює профресійну діяльність медичного працівника $є$ витребувана потребами сьогодення.

Мета роботи: з'ясувати існуючі права медичних працівників, передбачені чинним законодавством, з огляду на реформування системи охорони здоров'я.

Матеріали і методи. Для реалізації поставленої мети застосовано такий комплекс методів: порівняльно-правовий, структурно-логічний, системно-аналітичний, формально-логічний та метод теоретичного аналізу з дотриманням принципів біотичних норм і правил; фрормулювання і систематизація висновків.

Варто зазначити, що єдиного підходу до визначення правового статусу як юридичної категорії у науковій літературі немає. Так, частина вчених визначає правовий статус як комплексну інтеграційну категорію, що за своєю сутністю відображає взаємовідносини суб'єктів між собою, а також інші соціальні зв'язки [2, 4]. Інші науковці розглядають права і обов'язки суб'єктів правовідносин як основу їх правового статусу $[1,3,5,6]$. Різноманітність підходів до розуміння правового статусу вказує на відсутність одностайності серед вчених у цій царині юриспруденції і обумовлює необхідність вивчення прав і обов'язків лікаря, який є учасником правовідносин, що виникають у галузі охорони здоров'я. На сучасному етапі реформування національної системи охорони здоров'я одним із пріоритетних напрямків $€$ вдосконалення правового забезпечення профресійної діяльності лікарів.

Результати дослідження та їх обговорення. Основний Закон держави гарантує кожному громадянину право на охорону здоров'я та медичну допомогу (ст. 49 Конституції України). Реалізація цього права забезпечується низкою нормативно-правових актів, зокрема: законами України «Основи законодавства України про охорону здоров'я», «Про забезпечення санітарного та епідемічного благополуччя населення», «Про протидію поширенню хвороб, зумовлених вірусом імунодефріциту людини (ВІЛ), та правовий і соціальний захист людей, які живуть з ВІЛ», «Про донорство крові та її компонентів», «Про заходи протидії незаконному обігу наркотичних засобів, психотропних речовин і прекурсорів та зловживанню ними», «Про трансплантацію органів та інших анатомічних матеріалів людини», «Про психіатричну допомогу», «Про захист населення від інфекційних хвороб»; указами Президента України, наприклад, Указ Президента України «Про Стратегію сталого розвитку «Україна - 2020», що передбачає впровадження в Україні європейських стандартів життя, при чому, держава несе відповідальність перед суспільством за забезпечення гарантій кожному громадянину, незалежно від раси, кольору шкіри, політичних, релігійних та інших переконань, статі, етнічного та соціального походження, майнового стану, місця проживання, мовних або інших ознак, мати доступ до високоякісної освіти, системи охорони здоров'я та інших послуг у державному та приватному секторах; постановами Кабінету Міністрів України; нормативними наказами Міністерства охорони здоров'я, інструкціями тощо. У цій галузі затверджено загальнодержавну цільову соціальну програму протидії ВІЛ-інорекції/ СНІДу на 2014-2018рр. та ін.

Так, зокрема Закон України «Про державні фрінансові гарантії медичного обслуговування населення» затвердив Програму державних гарантій медичного обслуговування населення. У ній визначено перелік і обсяг медичних послуг (включно медичні вироби) та лікарських засобів, повну оплату надання яких пацієнтам держава гарантує за рахунок коштів Державного бюджету України згідно з тарифом, для профілактики, діагностики, лікування та реабілітації у зв'язку 3 хворобами, травмами, отруєннями і патологічними станами, а також через вагітність та пологи. У свою чергу, послуга з медичного обслуговування населення (медична послуга) надається пацієнту закладом охорони здоров'я або фрізичною особою - підприємцем, яка зареєстрована та отримала у встановленому законом порядку ліцензію на провадження господарської діяльності з медичної практики, та оплачується її замовником. Представником надавача і $€$ медичний працівник, який має право надавати медичну допомогу та перебуває з надавачем або залученою особою в трудових відносинах.

Відповідно до Положення про Національну службу здоров'я України, що затверджене Постановою Кабінету Міністрів України «Про утворення Національної служби здоров'я України», її завданням $€$ контроль за дотриманням умов медичного обслуговування населення. Тобто здійснення 
безпосереднього контролю за роботою лікарів та якістю надання медичних послуг. Разом із тим, у контексті медичної реформи необхідно виокремити права та обов'язки лікарів, адже обізнаність у правовому статусі є гарантією забезпечення їх належного виконання та дотримання.

Аналіз чинних нормативно-правових актів дає підстави стверджувати, що права медичних працівників необхідно розмежувати на дві групи: загальні та спеціальні. До загальних прав медичних працівників належать ті, які гарантують певні умови їх професійної діяльності (Кодекс законів про працю України, закони України «Про оплату праці», «Про відпустки» та ін.), охорону здоров'я, соціальний захист. Відповідно до ст. 77 «Основ законодавста України про охорону здоров'я», основного законодавчого акту, який регулює правовідносини у галузі охорони здоров'я, можна виокремити такі загальні права медичних працівників: право на належні умови професійної діяльності; право на обов'язкове страхування за рахунок власника закладу охорони здоров'я у разі заподіяння шкоди їхньому життю і здоров'ю у зв'язку з виконанням професійних обов'язків; право на створення медичних наукових товариств, профресійних спілок та інших громадських організацій; право на судовий захист; право на підтвердження кваліфікації, перепідготовку у відповідних закладах і установах; соціальну допомогу з боку держави у разі захворювання, каліцтва або в інших випадках втрати працездатності, що настала у зв'язку з виконанням професійних обов'язків; право на скорочений робочий день і додаткову відпустку; пільгові умови пенсійного забезпечення та пільгове надання житла; право на першочергову медичну допомогу і забезпечення лікарськими та протезними засобами тощо [5].

До спеціальних прав належать такі, які передбачені виключно для медичного працівника як спеціального суб'єкта. До таких прав належать право на заняття медичною діяльністю відповідно до спеціальності та кваліфікації; вільний вибір апробованих форм, методів і засобів діяльності, впровадження у встановленому порядку сучасних досягнень медичної та фрармацевтичної науки і практики; право про надання інорормації про пацієнта без його згоди чи згоди його законного представника; право на відмову від подальшого ведення пацієнта; право здійснювати медичне втручання без згоди пацієнта або його законних представників.

Незважаючи на нормативне визнання прав і обов'язків медичних працівників, варто констатувати, що правова регламентація професійної діяльності цієї категорії громадян у національному законодавстві потребує окремих доповнень і додаткових уточнень, зокрема частина прав медичних працівників, передбачених як міжнародними, так і національними нормативними приписами, має декларативний характер. Наприклад, Резолюція ПАРє № 1763, прийнята у 2010 р. передбачає право лікаря на заперечення з міркувань совісті при наданні легальної медичної допомоги. Разом із тим, це право не є універсальним і має обмеження. Лікар не може відмовитися надавати медичну допомогу на засадах зазначеного права без урахування наступних застережень:

1) право на заперечення застосовується тільки до виконання процедур, але не до надання інформації;

2) лікар зобов'язаний також інорормувати пацієнтів завчасно про будь-які заперечення з міркувань совісті та направляти пацієнтів до іншого виконавця медичних послуг;

3) право на заперечення не можливо застосовувати до ситуації, у якій особа потребує невідкладної допомоги.

Право лікаря на заперечення з міркувань совісті, у медичній практиці лікарі застосовують доволі часто у зарубіжних країнах. Так, у Німеччині лікар-акушер-гінеколог під час влаштування на роботу робить застереження про його право на відмову від здійснення процедури аборту (штучного переривання вагітності) з міркувань совісті. У разі звернення пацієнта, що дав згоду на проведення процедури штучного переривання вагітності, лікар-акушер-гінеколог повинен надати інші види медичного обслуговування (консультацію, діагностику, подальшу реабілітацію пацієнта після проведення цієї процедури). При цьому заклад охорони здоров'я зобов'язаний забезпечити пацієнта іншим кваліфікованим лікарем-акушергінекологом, який повинен надати вищезазначену медичну допомогу. В Україні, натомість, право лікаря на відмову від здійснення аборту (штучного переривання вагітності) 3 міркувань совісті прямо не передбачено. 3 цих підстав, чинне національне законодавство у галузі охорони здоров'я потребує вдосконалення шляхом внесення змін й визначенням механізму реалізації міжнародного права лікаря на заперечення під час виконання своїх професійних обов'язків.

Профресійні права і обов'язки лікарів регулюються чинним законодавством, що затверджує не лише фрахові вимоги, а й етико-деонтологічні. Проведений побіжний огляд вказує на необхідність уніфікації правової регламентації прав і обов'язків лікарів, їх доповнення та розширення в межах комплексного рефрормування системи охорони здоров'я.

\section{Висновки}

Серед передбачених у чинному національному законодавстві профресійних прав медичних працівників можна виокремити два основних 
види таких прав: загальні та спеціальні. Недосконалість існуючої нормативної бази стосовно юридичного статусу медичних працівників, недостатня увага та відсутність належного контролю 3 боку державних органів влади стосовно гарантій у забезпеченні законних прав медичних працівників нерідко зумовлює декларативний характер цих прав. Застосування зарубіжного досвіду, імплементація міжнародних стандартів у національне законодавство, зокрема щодо реалізації лікарем права на заперечення з міркувань совісті, забезпечить більш професійну захищеність лікаря та підвищить якість надання медичної допомоги.
Перспективи подальших досліджень. Вдосконалення правової регламентації професійної діяльності лікарів в Україні із запозиченням міжнародного досвіду та враховуючи практику ЄСПЛ у галузі охорони здоров'я, розроблення нових та доповнення існуючих медичних стандартів, затвердження міжнародних протоколів надання медичної допомоги, доповнення правового статусу лікаря належним обсягом прав і обов'язків та посилення контролю МОЗ України за дотриманням механізму їх реалізації на практиці забезпечить підвищення якості надання медичної допомоги населенню.

\section{Список літератури}

1. Калинюк Н. Юридична кваліфікація десектів надання медичної допомоги у сфері акушерства і гінекології / Н. Калинюк, І. Рогальський, Н. Гуменна // Медичне право. - 2015. - № 2 (16). - С. 63-73.

2. Сарибаєва Г. М. Законодавство України про охорону здоров'я: адміністративний вимір / Г. М. Сарибаєва // Вісник Південного регіонального центру Національної академії правових наук України. - 2017. - № 13. - С. $121-127$.

3. Сенюта I. Підстави виникнення правовідносин у сорері надання медичної допомоги: деякі аспекти / І. Сенюта // Науковий вісник Ужгородського національного університету. - 2018. - Т. 1, № 50. - С. 107-110.

4. Стефранчук P. О. Проведення в Україні кодифікації медичного законодавства: до питання постановки проблеми / Р. О. Стефранчук // Актуальні проблеми медичного права: професійний погляд : матеріали Всеукраїнської наук.практ. конор., Київ, 29 лист. 2018 р. - Одеса : Фенікс, 2019. - С. 124-129.

5. Стеценко С. Г. 25 років Основ законодавства України про охорону здоров'я: успіх, сумніви чи невдача? / С. Г. Стеценко // Актуальні питання теорії та практики правового регулювання галузі охорони здоров'я: проблеми і перспективи : матеріали наук.-практ. круглого столу, присвяч. 25-річниці прийняття Закону України «Основи законодавства України про охорону здоров'я», 17 лист. 2017 р. - Запоріжжя : Вид-во ЗДМУ, 2017. - С. 10-13.

6. Стеценко С. Г. Медична реформа в Україні: право, політика, мораль / С. Г. Стеценко // Публічне право. - 2017. № 4. - C. 57-61.

7. Стеценко С. Г. Трансформація сфрери охорони здоров'я України: роль медично-правових досліджень / С. Г. Стеценко // Актуальні проблеми медичного права: професійний погляд : матеріали Всеукраїнської наук.-практ. конор., Київ, 29 лист. 2018 р. - Одеса : Фенікс, 2019. - С. 120-123.

8. Франчук В. В. Місце, роль і значення лікарської профресії в умовах сучасного українського суспільства / В. В. Франчук // Вісник соціальної гігієни та організації охорони здоров'я України. - 2017. - № 3 (73) . - С. 35-41.

\section{References}

1. Kalyniuk, N., Rohalskyi, I., \& Humenna, N. (2015). Yurydychna kvalifikatsiia defektiv nadannia medychnoi dopomohy u sferi akusherstva i hinekolohii [Legal qualification of defects of medical aid in the field of obstetrics and gynecology]. Medychne pravo - Medical Law, 2 (16), 63-73 [in Ukrainian].

2. Sarybaieva, H.M. (2017). Zakonodavstvo Ukrainy pro okhoronu zdorovia: administratyvnyi vymir [Ukrainian Health Legislation: Administrative Dimension]. Visnyk Pivdennoho rehionalnoho tsentru Natsionalnoi akademii pravovykh nauk Ukrainy - Journal of the South Regional Center of National Academy of Legal Sciences of Ukraine, 13, $121-127$ [in Ukrainian].

3. Seniuta, I. (2018). Pidstavy vynyknennia pravovidnosyn u sferi nadannia medychnoi dopomohy: deiaki aspekty [The reasons for the emergence of legal relationships in the field of medical care: some aspects]. Naukovyi visnyk Uzhhorodskoho natsionalnoho universytetu - Scientific Herald of Uzhhorod University, 1, (50), 107-110 [in Ukrainian].

4. Stefanchuk, R.O. (2019). Provedennia v Ukraini kodyfikatsii medychnoho zakonodavstva: do pytannia postanovky problem [Conducting in Ukraine the codification of medical legislation: to the issue of problem setting]. Abstracts of papers: Aktualni problemy medychnoho prava: profesiinyi pohliad. (pp. 124-129), Kyiv. [in Ukrainian].

5. Stetsenko, S.H. (2017). 25 rokiv Osnov zakonodavstva Ukrainy pro okhoronu zdorovia: uspikh, sumnivy chy nevdacha? Abstracts of papers: Aktualni pytannia teorii ta praktyky pravovoho rehuliuvannia haluzi okhorony zdorovia: problemy i perspektyvy. (pp. 10-13), Zaporizhzhia [in Ukrainian].

6. Stetsenko, S.H. (2017). Medychna reforma v Ukraini: pravo, polityka, moral [Medical reform sn Ukraine: law, politics, moral]. Publichne pravo - Public Law, 4, 57-61 [in Ukrainian].

7. Stetsenko, S.H. (2019). Transformatsiia sfery okhorony zdorovia Ukrainy: rol medychno-pravovykh doslidzhen. Abstracts of papers: Aktualni problemy medychnoho prava: profesiinyi pohliad. (pp. 120-123), Kyiv [in Ukrainian].

8. Franchuk, V.V. (2017). Mistse, rol i znachennia likarskoi profesii v umovakh suchasnoho ukrainskoho suspilstva. Visnyk sotsialnoi hihiieny ta orhanizatsii okhorony zdorovia Ukrainy - Bulletin of Social Hygiene and Health Protection Organization of Ukraine, 3 (73), 35-41 [in Ukrainian]. 


\section{О ПРАВАХ МЕДИЦИНСКИХ РАБОТНИКОВ ПРИ ОКАЗАНИИ МЕДИЦИНСКОЙ ПОМОЩИ} В КОНТЕКСТЕ РЕФОРМИРОВАНИЯ СИСТЕМЫ ЗДРАВООХРАНЕНИЯ

И. Г. Савка ${ }^{1}$ Н. Н. Калинюк ${ }^{2}$

${ }^{1}$ ВГУЗ «Буковинский государственный медицинский университет», г. Черновцы, Украина

2ГВУЗ «Тернопольский государственный медицинский университет имени И. Я. Горбачевского МЗ Украины», г. Тернополь, Украина

Цель: определить права медицинских работников, предусмотренные действующим законодательством, учитывая реформирование системы здравоохранения.

Материалы и методы. Методологической основой исследования выступает совокупность общих и специальных научных методов познания. Действующие нормативно-правовые акты, проанализированы с помощью комплекса методов: сравнительно-правового, структурно-логического, системно-аналитического, фрормально-логического и метода теоретического анализа с соблюдением принципов биотических норм и правил; формулировка и систематизация выводов.

Результаты. Анализ действующих нормативно-правовых актов дает основания утверждать, что права медицинских работников следует разграничить на две группы: общие и специальные. К общим правам медицинских работников относятся условия труда, охрана их здоровья, социальная защита, в частности право на: надлежащие условия профессиональной деятельности; создание медицинских обществ, профессиональных союзов и других общественных организаций; судебную защиту; право на занятие медицинской деятельностью в соответствии со специальностью и квалификацией; подтверждение квалисикации, переподготовку в соответствующих заведениях и учреждениях. К специальным правам медицинского работника следует отнести следующие: право на инорормацию о пациенте без его согласия или согласия его законного представителя; право на отказ от дальнейшего ведения пациента; право осуществлять медицинское вмешательство без согласия пациента или его законных представителей.

Действующее национальное законодательство в сорере здравоохранения нуждается в совершенствовании. Одним из шагов на этом пути стала бы имплементация предусмотренного международными нормативными актами права врача на возражения во время выполнения своих профессиональных обязанностей.

Выводы. Права врача при оказании медицинской помощи следует разделить на общие и специальные. Закреплены в действующем национальном законодательстве профессиональные права врача, в основном, имеют декларативный характер. Это обусловлено отсутствием разработанных подзаконных актов, которые должны обеспечить механизм их реализации с учетом требований современности. Применение зарубежного опыта, имплементация международных стандартов в национальное законодательство, в частности по реализации врачом права на возражение по соображениям совести, обеспечит более профессиональную защищенность врача и повысит качество оказания медицинской помощи.

КЛЮЧЕВЫЕ СЛОВА: система здравоохранения; права; медицинский работник; медицинская помощь.

\section{TO THE RIGHTS OF THE MEDICAL PRACTITIONERS IN THE CONTEXT OF THE REFORMING OF THE HEALTH SYSTEM \\ I. H. Savka ${ }^{1}$, N. M. Kalyniuk ${ }^{2}$ \\ ${ }^{1}$ Bukovinian State Medical University, Chernivtsi, Ukraine \\ ${ }^{2}$ I. Horbachevsky Ternopil State Medical University, Ternopil, Ukraine}

Purpose: definition of the rights of medical workers while medical aid in the context of reformation of the health care system.

Materials and Methods. The methodological basis of the research is a set of general and special scientific methods of cognition. The current normative-legal acts, analyzed using a set of methods: comparative-legal, structural-logical, system-analytical, formal-logical and method of theoretical analysis, observing the principles of biotic norms and rules; formulation and systematization of conclusions.

Results. The analysis of the current normative-legal acts gives grounds to confirm that the rights of medical workers should be divided into two groups: general and special. The general rights of medical workers include working conditions, the protection of their health, social protection, the right to appropriate conditions of professional activity; the right to establish medical scientific societies, trade unions and other public organizations; the right to judicial protection; the right to medical activities in accordance with specialty and qualification; the right to confirm qualification, retraining in the appropriate institutions and establishments. The special rights of a health worker should include the following: the right to provide information about the patient without his consent or the consent of his legal representative; the right to refuse the further care of a patient; the right to medical intervention without the consent of the patient and/or his legal representatives.

Conclusions. The rights of a doctor while medical aid should be divided into general and special. The professional rights of a doctor, which are noted in the current national legislation, are, for the most part, declarative. This is due to the lack of developed by-law acts, which should provide the mechanism for their implementation, 
taking into account the requirements of nowadays. The application of foreign experience, the implementation of international standards into national legislation, in particular regarding the implementation of doctor's right to object on the grounds of conscience, will provide more professional protection of a doctor and improve the quality of medical care.

KEY WORDS: health care system; rights; legal status; doctor; medical aid.

Рукопис надійшов до редакції 11.03.2019 p.

\section{Відомості про авторів:}

Савка Іван Григорович - доктор медичних наук, професор кафедри судової медицини та медичного правознавства ВДНЗ «Буковинський державний медичний університет».

Калинюк Наталія Миколаївна - кандидат юридичних наук, доцент кафедри педагогіки вищої школи та суспільних дисциплін ДВНЗ «Тернопільський державний медичний університет імені І. Я. Горбачевського МОЗ України»; тел.: +38(0352) 52-48-87. 